\title{
ASSESSMENT OF EXPANDED STYROFOAM AND POLYURETHANE AS A SUSTAINABLE BUILDING MATERIALS; MUBI GENERAL HOSPITAL ADAMAWA STATE, NIGERIA
}

\author{
Joshua Y. VAWA 10 and Paul Magaji MANGA \\ Department of Architecture, Faculty of Environmental Sciences Modibbo Adama University, Yola \\ Adamawa State, Nigeria
}

Research Article

PII: S238315532100001-10

Received: 29 March 2021

Revised: 25 May 2021

Published: 15 June. 2021

Corresponding author:

E-mails: Yamte1991@gmail.com Talk5jvawah@gmail.com

Tel: +2349032963354,

$+2348057991396$

\begin{abstract}
This study assesses the perception of stakeholders on the use of expanded Styrofoam (EPS) for building construction in Nigerian construction industry. It identified both organizations and individuals with great enthusiasm in the production and use of EPS for building construction but this has not been rewarded with an enabling environment. This inevitably results in the slow pace of adoption of EPS in the building construction industry. Other factors are low knowledge base of the public about the workings (source, production, installation, and variant uses) of EPS is a critical impeding factor in the adoption pace. The used of structures questionnaires was used to collect data from randomly selected respondents. The data analyzed from this study indicates that all benefits expected from the use of an EPS constructed building were mostly derived most especially its sustainable attributes.
\end{abstract}

KEYWORDS: Expanded Styrofoam, Buildings, Environment, Sustainability, Construction and building materials.

\section{INTRODUCTION}

The use of building materials is very vital in all phases of life as no field of building and engineering is conceivable without their use and there is always a new technology to replace an outgoing technology due to mans' technological advancement. The use of building materials has changed from one material to another over the period of time due to technological advancement. The eco-friendly nature of Expanded Polystyrene Systems (EPS) has increased its versatility and use in commercial and residential construction $[1,2]$. Hence, it is expected that waste will occur. In a bid to enhance resource conservation and sustainable development, Adedeji and $\mathrm{Fa}$ [3] gives an overview on Recycled Foam and Cement Composites in Insulating Concrete Forms (ICF). EPS can be recycled until infinity times $[4,5]$. A "foam" with the ability to undergo recycling after use is the Expanded Styrofoam [6].

Goodier [7] stated that after man has eaten, the next line of struggle is shelter against various climatic conditions (sun/rain, wind/heat). The quest for shelter has made man in seek for number of materials varying from clay/mud, grass, stones, metals, plastics, blocks/bricks even Styrofoam. According to John [8] building materials are those materials that are used in construction of building. He further explained that the use of materials is vital aspect in which no field of engineering survive without their use as there is always need for replacement for the outgoing technology due to man's advancement in technology.

Over the time, the use of building materials has shifted ground from the conventional one to modern ones due to the advancement in the technology which has turn out to the production and use of expanded Styrofoam blocks in construction of building.

Styrofoam is a thermoplastic material obtained by the polymerization of styrene and is used in Packaging electronics, food items and building houses. Polystyrene is a light synthetic material which cannot be used in building houses unless it has been expanded to form a block. Sustainability means meeting our own needs without compromising the ability of future generations to meet their own needs. In addition to natural resources, we also need social and economic resources.

Sustainable materials are used in many industries as they create fewer long-term environmental problems and lead to a healthier planet. Awareness and use of sustainable materials are important to your small business: Besides being better for the earth, customers like them too.

Goodier [7] indicated that Expanded Polystyrene Systems (EPS) is sustainable material as the 
excellent acoustic, fire resistance, excellent thermal resistance and structural strength of it are considerably resilient due to the monolithic nature that amount it an exceptional building material. Despite the uniqueness, merit and significant of Expanded Polystyrene Systems (EPS) material, the use in building construction in Nigeria building industry is still precisely low.

Expanded Styrofoam or EPS, an organic insulation that demonstrates a positive eco-balance, is a rigid cellular plastic which is made from expandable Styrofoam containing an expansion agent, pentane. As a building material, Expanded Styrofoam Systems (EPS) has found applications in many aspects of building works including large structures such as roads, bridges, railway lines and public buildings. In addition to its eco-friendly nature, Expanded Polystyrene Systems (EPS) exhibits low thermal conductivity, lightweight, mechanical resistance, moisture and chemical resistance, ease of handling and installation and versatility, which makes it more suitable for building construction than the conventional sandcrete system $[9,10]$.

For construction purposes Drysdale [11] noted that two energy-efficient systems relying on EPS are insulating concrete forms (ICFs) and structural insulated panels (SIPs). Both are recognized as innovative product solutions used to construct building envelopes and are gaining wide acceptance by leaders in sustainable designs, shown in fig. 2.0 \&2.1. Expanded polystyrene has been found to offer substantial environmental advantages through energy saving and greenhouse gases emission reduction and is therefore ideally suited to the creation of environmentally-friendly new building projects [12].

The aim of this study is to assert that there is a need for the use of Expanded Polystyrene Systems (EPS) as a sustainable substitute to the traditional building material (block and brick) in the building industry. For the purpose of achieving the aim of this research the following objectives are as follows:

1- To evaluate the usability of Expanded Polystyrene Systems (EPS) as a material for construction;

2- To assess the effectiveness of Expanded Polystyrene Systems (EPS) as a material for construction;

3- To assess the cost effectiveness of Expanded polystyrene System (EPS) as a material for construction.

\section{INSULATED CONCRETE FORMS}

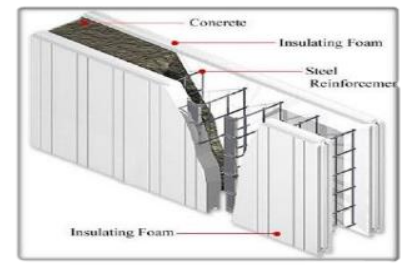

HOMES BEING BUILT WITH ICFS HAVE THE INSULATIONS BUILT INTO THE WALLS AS PART OF THE SURFACE. THESE SYSTEMS CREATE WALLS THAT
HAVE A HIGH THERMAL RESISTANCE. THEY ALSO PROVIDE A BACKING FOR DRY WALL ON THE INSIDE,AS WELL AS STUCCO, SIDING OR BRICK FO THE OUTSIDE.

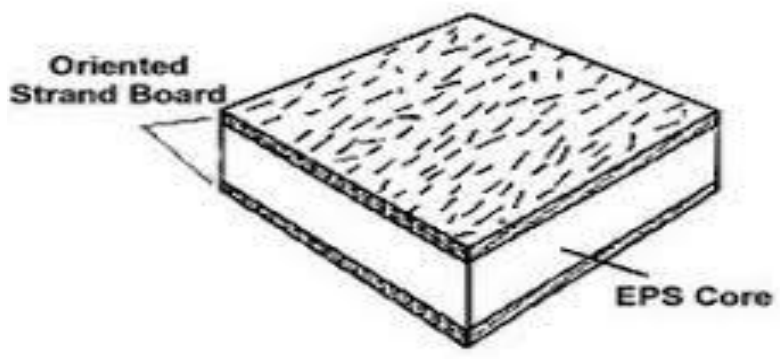

Sulong et al. [13].

In recent years, there has been an explosive growth of interest in the application of expanded polystyrene (EPS) for construction industry. EPS is a well-established insulation material used for various applications as it has a light yet rigid foam with good thermal insulation and high impact resistance. Apart from that, it possesses high load-bearing capacity at low weight, absolute water and vapor barrier, air tightness for controlled environments, long life, low maintenance, fast, and economic construction. The foam in EPS is a lightweight cellular plastic consisting of small spherical-shaped particles containing about $98 \%$ air. This microcellular closed cell construction provides Expanded Polystyrene Systems (EPS) with its excellent insulating and shock absorbing characteristics [13].

Expanded Polystyrene Systems (EPS) consists of small polystyrene beads that derived from styrene via polymerization process [9]. The foam quality of EPS is affected by the size distribution of the beads. After the polymerization, EPS is infused with blowing agent such as pentane and hexane.

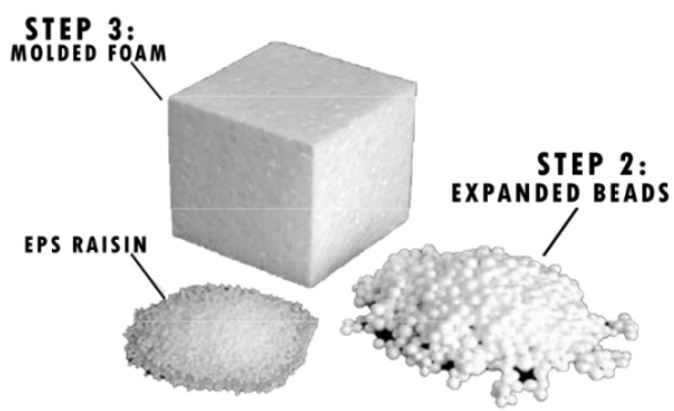

Ogundiran and Adedeji [9]. 
Small polystyrene beads and a molded form of ESP after polymerization

The conversion of polystyrene beads to EPS is carried out in three stages: 1) pre-expansion; 2) intermediate maturing and stabilization; and 3) expansion and final molding.

In the first stage, the raw material is heated in pre-expanders with steam at temperature between $80^{\circ} \mathrm{C}$ and $100^{\circ} \mathrm{C}$ to create a relatively uniform cellular structure with small closed cells that hold air in their interior. According to Kellenberger et al. [10] during this process, the beads' internal gas experience volume expansion that generates air-penetrable cellular structure. This process is carried out in aerated silos during the material's intermediate maturing. Based on the air temperature, size, and density of the beads, the aging time is calculated. The beads achieve greater mechanical elasticity and improved expansion capacity. Through the expansion process, the stabilized pre-expanded beads are molded and re-exposed to steam in order to bind the beads. Blocks created using this process is further enhanced in terms of dimensional stability prior to separation into required shape.

\section{Significance of the study}

Due to man's insatiable desire to enhance on the present, revolution and improvement on the current is an unavoidable action. The use of building materials changes with time due to increased options of building materials to choose from as a result of technological advancement. This advancement has led to the production and use of polystyrene in building construction.

Expanded Polystyrene System (EPS) has been proven to possess all functional requirements that contribute to the overall integrity of any building in both form and content. Comparative test and analysis of Expanded Polystyrene Systems (EPS) and Sandcrete hollow blocks in wall have conclusively validated that EPS has advantage over Sandcrete block in urban housing delivery in Nigeria. However, according to Ogundiran and Adedeji [9] its slow pace of adoption in Nigeria construction industry is a cause for concern.

Ogundiran and Adedeji [9] endorses the intensification of research efforts on the material towards achieving sustainable housing delivery in Nigeria. The study further emphasizes that mass production should be given to the material to ensure cost efficiency and better patronage in the construction of housing units. To achieve a boost in the Nigerian construction industry and better urban housing delivery in Nigeria, there is the need to investigate into the causes of the slow pace of adoption and course a path for further research to tackle such reasons. This in turn will enhance proper resource conservation that invariably leads to sustainable development. This research therefore intends to create awareness, examine the factors associated with Expanded Polystyrene Systems (EPS) and the conscious understanding of those with keen interest of the Expanded Polystyrene Systems (EPS) technology.

\section{Scope of the study}

This study examined the sustainability and effectiveness of the use of Expanded Polystyrene Systems (EPS) in the research location which is Mubi General Hospital Adamawa state. The work will examine the buildings against the Green Building Index (GBI) checklist to determine its sustainability.

\section{The concept of sustainable development and green architecture}

The topical issue of sustainable development which encompasses sustainable design and construction as it relates to architecture is not new and has witnessed considerable growth in literature over the last two decades [16]. Sustainable development has now become a worldwide trend to scale down the negative impact of man's activity on the environment [17]. It has been widely asserted by many authors that sustainable development is about "meeting the needs of the present without compromising the ability of future generations to meet their own needs" [18]. It is in this regard Ilesanmi [16] remarked that the concept of sustainability attempts to achieve simultaneously the goals of an improved environment, a better economy, and a more just and participative society, rather than trading off any one of these against the others. In relation to the field of architecture, sustainability or sustainable development has given birth to the concept of sustainable architecture or green architecture. Green architecture is a general term that describes environmentally-conscious design techniques in the field of architecture and it is framed within the larger context of the discussion of sustainability [19].

Today, interest in sustainable "green" building is growing worldwide and the movement began as a result of the need and desire for more energy efficient and environmentally friendly construction practice by taking advantage of renewable resources and energy. Green buildings often include measures to reduce energy use and increase the efficiency of 
the building envelope. A number of excellent and well proven environmental evaluation schemes such as the Building Research Establishment Environmental Assessment Method (BREEAM) of Building Research Establishment (BRE) of the UK, the Leadership in Energy and Environmental Design (LEED) of the United States Green Building Council (USGBC) of the USA, Haute Qualite Environmental (HQE) of France and the Green Star of Australia are already in existence. They all set standards for the best practice in sustainable design and have become the modern yardstick for measuring and describing a building's environmental performances. Green buildings therefore often include measures to reduce energy use and increase the efficiency of the building envelope [19, 20].

According to Manual for Expanded Polystyrene (EPS) core panel system and its field application (June 2017) Expanded Polystyrene (EPS) core panel system is a modern, efficient, safe and economic construction system for the construction of buildings. These panels can be used both as load bearing as well as non-load bearing elements. Expanded Polystyrene Systems (EPS) core panel is a 3 D panel consisting of 3 -dimensional welded wire space frame provided with the polystyrene insulation core. Panel is placed in position and shotcrete on both the sides. The EPS panels consist of a $3^{-}$ dimensional welded wire space frame utilizing a truss concept for stress transfer and stiffness.

EPS panel includes welded reinforcing meshes of high-strength wire, diagonal wire and selfextinguishing expanded polystyrene uncoated concrete, manufactured in the factory and shotcrete is applied to the panel assembled at the construction site, which gives the bearing capacity of the structure.

\section{Properties of EPS}

\section{Fire behavior and thermal insulation properties of EPS}

Polystyrene foam has similar fire behavior to most organic materials where both are easily combustible. Thus, tiny amount $(<1 \%)$ of fireretardant material is added to the EPS insulation product in order to enhance the fire retardancy of EPS. Besides fillers such as $\mathrm{SiO}_{2}, \mathrm{Fe}_{2} \mathrm{O}_{3}$, and clay, waste such as fly ash can also be used as cheaper alternative to increase the flame retardant of EPS foams [18]. Wang et al. [21] introduced fly ash into phenolic resin-hydrated aluminium hydroxide binder which is the incorporated into EPS foam. This insulation material is reported to increase the loss on ignition (LOI) value of EPS foam up to $29.6 \%$ and acquired the V-o rating. The leaching of fireretardant material into environment is prevented since it is polymerized into the molecular structure of EPS.

Miao et al. [22] studies were conducted on thermal insulation properties of EPS as construction and insulating materials. Thermal conductivity test provides information that determines the performance and suitable application for the insulating material. As construction equipment, insulation material has to comply with parameters such as temperature, humidity, and overall assembly condition.

\section{Production of smoke}

Smoke is described as visible suspension of solid or liquid particles in the gas as product of combustion and pyrolysis. Production of smoke can be suppressed by restricting the ability of material to ignite and reducing the flame spread and heat released.

The surface area of EPS insulation must be protected using non-combustible material in order to minimize smoke production during event of fire [11]. EPS begins to soften at temperature above $100^{\circ} \mathrm{C}$ and upon further heat exposure, it will shrink, melt, and decompose to produce flammable gases which ignitable by spark or flame at certain condition and temperature.

\section{Mechanical strength of EPS}

Studies were conducted to understand how grain size of EPS and additives such as fly ash and silica fume can enhance the mechanical properties of EPS-aggregated concrete [23]. performed research on the durability of EPS mortar. In this article, several methods were used to observe microstructure in order to analyze the effect of EPS type and concentration on the strength of Portland cement mortars. Methods employed were capillary absorption of water, mercury intrusion porosimetry, impendence spectroscopy, and open porosity.

The EPS product is classified based on compressive strength and compressive stress. Compressive strength is maximum uniaxial compressive stress that material can bear before fracturing. Number is assigned to EPS product based on its compressive stress at $10 \%$ compression.

\section{Water and moisture absorption}

EPS has very poor water absorption which decreases as density increases. EPS with 9-12 years 
of usage period has $8 \%-9 \%$ of its volume filled under groundwater table [24]. The cellular structure of EPS is water resistant, vapor permeable, and possesses zero capillarity though neither liquid water nor water vapor influences its mechanical properties. However, absorption of moisture is still possible upon complete immersion of EPS due to fine interstitial channels between molded beads.

EPS geofoam is prone to moisture absorption which causes deterioration of thermal properties. Less than $10 \%$ volume of lightweight-fill geofoam is absorbed during its lifetime usage [25]. Also, high density EPS possesses high water vapor diffusion resistance factor due to better moisture properties.

\section{Chemical resistance}

Chemical resistance of EPS is affected by the reaction time, temperature, and applied stress. It has identical resistance to general polystyrene. EPS is sensitive toward solvent attack which leads to softening and cracking of itself due to its thin cell walls and large exposed surface.

EPS does not react with water, salt, or alkali solution. The insolubility of EPS in most organic solvent influences the selection of adhesive, label, and coating of EPS product. In general, substance is tested for its compatibility with EPS by exposing molded polystyrene to it at 120-140 F. Despite the ultraviolet radiation resulted in superficial yellowing and friability on molded polystyrene, its physical properties remain unaltered.

\section{Toxicity and environmental effect}

EPS is a polymer derived from styrene monomer, a hydrocarbon with molecular compound of $\mathrm{C}_{8} \mathrm{H}_{8}$ that burns completely in the presence of excess oxygen to produce carbon dioxide, $\mathrm{CO}_{2}$, and water as shown in eq. (1).

\section{$\mathrm{C}_{8} \mathrm{H}_{8}+10 \mathrm{O}_{2} ! 8 \mathrm{CO}_{2}+4 \mathrm{H}_{2} \mathrm{O} ð 1 \mathrm{P}$}

As reported by Doroudiani and Omidian, ${ }^{2}$ the amount of oxygen available during combustion affects the volume of soot and carbon monoxide, $\mathrm{CO}$ evolved. In theory, the complete combustion of $1 \mathrm{~g}$ of polystyrene requires roughly $2150 \mathrm{~cm}^{3}$ of oxygen. Since this huge amount of oxygen is not usually accessible during combustion, polystyrene burns partially to produce more soot and $\mathrm{CO}$ as shown in eq. (2).

$\mathrm{C}_{8} \mathrm{H}_{8}+10 ð-0: 75 \mathrm{xPO}_{2} ! \mathrm{xC}+\mathrm{xCO}+8$ ð $-2 \mathrm{xPCO}_{2}+$ $4 \mathrm{H}_{2} \mathrm{O}$ ð2

The volume of smoke and toxic gases released by EPS insulation material is determined by the material quantity and density. Normally, the surface of EPS insulation is fire-protected using gypsum, stone, wood or steel to prevent flame from spreading to EPS. Under normal fire situation, EPS melts due to heat flow. However, EPS might ignite when surface protection material is fully incinerated thus exposing it to direct fire followed by emission of smoke and combustion gases. The effect of fireretardant material on the toxicity of EPS is negligible due to only small addition (0.5-0.1\%) of the material is required. Hence, EPS produces significantly less toxic fumes as compared to natural material, for example, wood, wool, or cork [26].

Table 1. The properties EPS panels

\begin{tabular}{llc}
\hline $\mathbf{S} / \mathbf{N}$ & PROPERTIES & \\
\hline $\mathbf{1}$ & Density of EPS & $16-640 \mathrm{~kg} / \mathrm{m}^{3}$ \\
\hline $\mathbf{2}$ & Young's Modulus & $3000-3600 \mathrm{MPa}$ \\
\hline $\mathbf{3}$ & Tensile strength (st) & $46-60 \mathrm{MPa}$ \\
\hline $\mathbf{4}$ & Elongation at break & $3-4 \%$ \\
\hline $\mathbf{5}$ & Notch test & $2-5 \mathrm{kj} / \mathrm{m}^{2}$ \\
\hline $\mathbf{6}$ & $\begin{array}{l}\text { Glass transition } \\
\text { temperature }\end{array}$ & $100^{\circ} \mathrm{C}$ \\
\hline $\mathbf{7}$ & Vicat B & $90^{\circ} \mathrm{C}$ \\
\hline $\mathbf{8}$ & $\begin{array}{l}\text { Linear expansion } \\
\text { coefficient(a) }\end{array}$ & $8 \times 10^{-5} / \mathrm{k}$ \\
\hline $\mathbf{9}$ & Specific heat & $1.3 \mathrm{kj} /(\mathrm{kg} . \mathrm{K})$ \\
\hline $\mathbf{1 0}$ & Water absorption (ASTM) & $0.03-0.1$ \\
\hline $\mathbf{1 1}$ & Decomposition & X years, still \\
\hline
\end{tabular}

Source: EVG, (2001)

\section{Acoustic Properties}

Expanded polystyrene, when used in combination with other building materials effectively reduces the transmission of airborne sound through partitioned walls, ceilings and floors. EPS has the advantage of being lightweight and effective in thicknesses as low as $0.625 \mathrm{~cm}$ it can replace thicker, heavier materials.

\section{Recyclability}

EPS is $100 \%$ recyclable. There are two main types of plastic resins mainly thermoplastics and thermosets. Thermosets cannot be re-melted but thermoplastics can be recycled and changed into various types. Polystyrene is a thermoplastic family and is suitable for recycling [26].

Recycling has been an area of concern coupled with eco-efficiency [28]. The process can take various forms; it can be reused in non-foam 
applications such as lightweight concrete. The recycling process of EPS is carried out such that it transforms into polystyrene plastic after the process.

\section{MATERIAL AND METHOD}

\section{Study Area}

Mubi city and its immediate environment constitute the study area for this research. Mubi, town, northeastern Adamawa state, northeastern Nigeria. It lies on the west bank of the Yedseram River, a stream that flows north into Lake Chad, and is situated on the western flanks of the Mandara Mountains.

Probably founded in the late 18th century by the Fulani people, Mubi remained under the jurisdiction of the sultanate of Mandara until conquered in the Fulani jihad (holy war) by Modibbo Adama. By the 1820 s the peoples of Mubi and the surrounding area were incorporated into Adama's Fulani kingdom of Fumbina, later called Adamawa; in the 1890 os they were subjected to slave raids by Adamawa's emir Zubeiru. The town was taken by German forces in 1903 and served as a frontier post and administrative centre of German Kamerun until its capture by the British in 1914 . Mubi and its surrounding region were placed in the British Cameroons by a League of Nations mandate in 1922. In 1961 it became part of Nigeria. The town is the site of a federal polytechnic college. Pop. (2006) local government area, 280,009.

Between 305 to 610 meters above the sea level. To the south-east of jalingo, the land rises to the peak of about 914 meters, which forms the watershed for river benue. There are also pockets of hills to the north including jalingo hill, Hosere hill, Jauro Ashe hill, and Dambature hills ranging from the heights of 323 to 349 meters. There hills form interesting features in the landscape of jalingo city. The city slopes gently in nature, hence making it self-draining to River Lamurde.

The study tends to find out the opinion of respondents on the use of expanded polystyrene in construction and its level of acceptability in the Nigerian society while also considering its architectural implications. Hence, respondents will give their opinions based on the usability and effectiveness of expanded polystyrene.

The researcher will collect data using questionnaires which will be administered by the respondents. All the respondents are expected to give maximum cooperation as the information on the questionnaire are all on things that revolve around the study. Hence, time will be taken to explain how to tick or indicate their opinion on the items stated on the research questionnaires. The data obtained through questionnaires will be analyzed and tabulated based on descriptive, statistical methods using frequency and remarks. In this study, mean was used to analyze the data collected. A four point Likert scale was used to analysis each of the questionnaire items.

\section{RESULTS}

The purpose of this study was assessment of stakeholders on the use of expanded polystyrene (EPS) for building construction in Nigeria, requires that data be obtained from the under listed stakeholders; 1) Architects; 2) Engineers; 3) Builders; 4) Quantity surveyors.

The analysis will be categorized according to data obtained, which are sequentially arrange. The data collected for this study were analyzed statistically and presented in this chapter. The data collected were organized in consonance with the research questions on the questionnaire. This was followed by data analysis that resulted in some findings. The result of data collected by the researcher through the use of questionnaire are therefore presented below.

The form of administration of the questionnaire to the respondents by the researcher is by hand. However, among the 40 respondents who questionnaires were distributed to; only 25 (twentyfive) questionnaires were recovered. Therefore, only the questionnaire of 25 respondents which represents about $62.5 \%$ response rates was recovered. However, fifteen questionnaires were unable to be recovered which represents about $37.5 \%$,

What is the usability of Expanded Polystyrene Systems (EPS) as a material for construction?

Table 2 shows $20 \%$ of respondents were engineers, $56 \%$ are Architects, $8 \%$ quantity surveyors and $12 \%$ builders. We can therefore deduce that virtually all the professions in the construction industries are well represented and as such elicit a uniform and unbiased response.

According to table 3, the result obtained from the field is that ESP is the easiest material to use when compared to other building material. Again, it has some merits over other materials such as: fast erection time/installation. Going by the mean decision rule the mean response is 3.72 , the respondent agrees that it is the easiest to use. 
Table 4 shows the response of respondents rating the durability of ESP in construction. The mean rule of the above table is 3.04, according to the adopted decision rule the mean response is 3.04 rates makes it a more durable material in construction.

Table 2. Demography of respondent profession of respondents

\begin{tabular}{lcc}
\hline Variable & Frequency & Percentage \\
\hline Architects & 14 & 56 \\
\hline Quantity surveyors & 2 & 8 \\
\hline Builders & 3 & 12 \\
\hline Engineers & 5 & 20 \\
\hline Non professionals & 1 & 4 \\
\hline Total & 25 & 100 \\
\hline
\end{tabular}

Source: Researchers field study, (2021)

Table 3. Compared to other building material EPS is the easiest to use

\begin{tabular}{l|c|c|c|c}
\hline Response & $\mathbf{X}$ & Frequency & $\mathbf{F ( x )}$ & Percentage \\
\hline Strongly Agree & 4 & 18 & 72 & 72 \\
\hline Agree & 3 & 7 & 21 & 28 \\
\hline Disagree & 2 & 0 & 0 & 0 \\
\hline Strongly disagree & 1 & 0 & 0 & 0 \\
\hline Total & 10 & 25 & 93 & 100 \\
\hline
\end{tabular}

Source: Researchers field study, (2021)

Table 4. Expanded polystyrene (EPS) is a more durable building material in construction

\begin{tabular}{l|c|c|c|c}
\hline Response & $\mathbf{X}$ & Frequency & F(x) & Percentage \\
\hline Strongly Agree & 4 & 10 & 40 & 40 \\
\hline Agree & 3 & 8 & 24 & 32 \\
\hline Disagree & 2 & 5 & 10 & 20 \\
\hline Strongly disagree & 1 & 2 & 2 & 8 \\
\hline Total & 10 & 25 & 76 & 100 \\
\hline
\end{tabular}

Source: Researchers field study, (2021)

How effective is the use of Expanded Polystyrene Systems (EPS) in construction of building?

Table 5 shows the response of respondents rating the effectiveness of ESP in construction. The mean rule of the above table is 2.76 , according to the adopted decision rule the mean response is 2.76 rates makes it a more effective material when compared to other building material (block and brick) construction. Base on the table 6 the response obtained from the respondent is that expanded polystyrene is a more sustainable building material, Other EPS empirical merits from various perspective outlined in the literature review such as: fast erection time/installation, improved technology, save cost, quality of product and reduced weight, shorter construction time, costs savings both at initial level and whole life cycle, thermal and sound Insulation, water-tight nature, recyclability, perfect in-fill and finishing material, durable nature and strength also reflects from the responds of the respondents. According to the adopted decision rule the mean response is 3.08 rates makes it a more sustainable material in construction.

Table 5. EPS as a building material is more effective than other building material (block \& brick)

\begin{tabular}{l|c|c|c|c}
\hline Response & $\mathbf{X}$ & Frequency & $\mathbf{F ( x )}$ & Percentage \\
\hline Strongly Agree & 4 & 6 & 24 & 24 \\
\hline Agree & 3 & 10 & 30 & 40 \\
\hline Disagree & 2 & 6 & 12 & 48 \\
\hline Strongly disagree & 1 & 3 & 3 & 12 \\
\hline Total & 10 & 25 & 69 & 100 \\
\hline
\end{tabular}

Source: Researchers field study, (2021)

Table 6. EPS is a more sustainable building material

\begin{tabular}{l|c|c|c|c}
\hline Response & $\mathbf{X}$ & Frequency & $\mathbf{F ( x )}$ & Percentage \\
\hline Strongly Agree & 4 & 4 & 16 & 16 \\
\hline Agree & 3 & 19 & 57 & 76 \\
\hline Disagree & 2 & 2 & 4 & 8 \\
\hline Strongly disagree & 1 & 0 & 0 & 0 \\
\hline Total & 10 & 25 & 77 & 100 \\
\hline
\end{tabular}

Source: Researchers field study, (2021)

Table 7 indicates that the response of the respondents rating the range at which ESP covers in necessary elements for construction. Here $32 \%$ strongly agree to it while $40 \%$ agree, $24 \%$ disagree, $4 \%$ strongly disagree. Judging by our decision rule the mean response of 3.08 makes it a necessary material for construction.

Table 7. EPS covers a wider range of construction elements necessary for a building

\begin{tabular}{l|c|c|c|c}
\hline Response & $\mathbf{X}$ & Frequency & $\mathbf{F ( x )}$ & Percentage \\
\hline Strongly Agree & 4 & 8 & 32 & 32 \\
\hline Agree & 3 & 10 & 30 & 40 \\
\hline Disagree & 2 & 6 & 12 & 24 \\
\hline Strongly disagree & 1 & 1 & 1 & 4 \\
\hline Total & 10 & 25 & 77 & 100 \\
\hline
\end{tabular}

Source: Researchers field study, (2021)

According to table 8, the result obtained from the field is that ESP is can be molded into whateer 
form, making its application versatile various areas of building such as: concrete facial, monuments e.t.c. Again it has some merits over other materials such as: fast erection time/installation. Going by the mean decision rule the mean response is 3.24 , the respondent agrees that it is flexible to use.

Table 8. EPS can be molded into whatever form as desired by the user and that gives it an advantage over other building materials

\begin{tabular}{l|c|c|c|c}
\hline Response & $\mathbf{X}$ & Frequency & $\mathbf{F ( x )}$ & Percentage \\
\hline Strongly Agree & 4 & 6 & 24 & 24 \\
\hline Agree & 3 & 19 & 57 & 76 \\
\hline Disagree & 2 & 0 & 0 & 0 \\
\hline Strongly disagree & 1 & 0 & 0 & 0 \\
\hline Total & 10 & 25 & 81 & 100 \\
\hline
\end{tabular}

Source: Researchers field study, (2021)

\section{What is cost level of expanded polystyrene system (EPS) as a material for construction?}

Table 9 shows the response of respondents rating the building when it comes to affordability of materials in the construction industry. The mean rule of the above table is 2.76 , according to the adopted decision rule the mean response is 2.76 rates makes it a more affordable material for construction in the building industry.

Table 9. EPS is a more affordable construction material

\begin{tabular}{l|c|c|c|c}
\hline Response & $\mathbf{X}$ & Frequency & $\mathbf{F ( x )}$ & Percentage \\
\hline Strongly Agree & 4 & 3 & 12 & 12 \\
\hline Agree & 3 & 15 & 45 & 60 \\
\hline Disagree & 2 & 5 & 10 & 20 \\
\hline Strongly disagree & 1 & 2 & 2 & 8 \\
\hline Total & 10 & 25 & 46 & 100 \\
\hline
\end{tabular}

Source: Researchers field study, (2021)

Table 10 shows the response of respondents rating the building when it to maintenance of ESP in construction. The mean rule of the above table is 1.84 , according to the adopted decision rule the mean response is 1.84 rates makes it a poor when it comes to maintenance of the building in construction.

Base on the result from the table 11, the response of respondents rating about the availability of ESP in construction industry is poor. The mean rule of the above table is 2.0 rates which makes it a poor when it comes to availability of ESP as a material in building construction.

Table 10. The use of EPS as building material makes building maintenance easier

\begin{tabular}{l|c|c|c|c}
\hline Response & X & Frequency & F(x) & Percentage \\
\hline Strongly Agree & 4 & 0 & 0 & o \\
\hline Agree & 3 & 3 & 9 & 12 \\
\hline Disagree & 2 & 15 & 30 & 60 \\
\hline Strongly disagree & 1 & 7 & 7 & 28 \\
\hline Total & 10 & 25 & 46 & 100 \\
\hline
\end{tabular}

Source: Researchers field study, (2021)

Table 11. It is a readily available building material

\begin{tabular}{l|c|c|c|c}
\hline Response & $\mathbf{X}$ & Frequency & $\mathbf{F ( x )}$ & Percentage \\
\hline Strongly Agree & 4 & 0 & 0 & 0 \\
\hline Agree & 3 & 5 & 15 & 20 \\
\hline Disagree & 2 & 15 & 30 & 60 \\
\hline Strongly disagree & 1 & 5 & 5 & 20 \\
\hline Total & 10 & 25 & 50 & 100 \\
\hline Source: Resear
\end{tabular}

Source: Researchers field study, (2021)

\section{DISCUSSION}

On the perception of stakeholders on the usage of EPS as a building material, A good number of the respondents have appreciable knowledge about both the manufacture and use of EPS in building construction. They are aware of a variety of uses to which EPS can be put: in walls, ceiling or floor, beads for decorative purposes in buildings such as: furniture, dado rails, cornices, bean bags, throw pillows and use it as in -fill core for flush doors. Innovation is still in progress as the technology is driven towards other potential uses of the material.

Findings indicated that the cause of slow adoption pace of EPS for building construction in Nigeria mainly stems from the awareness of the public, the petrochemical sector and the power sector of the Nigeria.

On the issue of awareness, respondents suggest that EPS should be introduced into Nigerian universities to further study the other factors that can enhance its usage in Nigeria, enlighten the general public about the benefits that can be derived from EPS panels, and furthermore train individuals on how to handle and install EPS panels on sites.

The factors that influence the usage of EPS as a building material largely merits the erection time of the panels, the life span of the material, the structural stability, the versatility of EPS panels and 
its economic viability as a building material. Environmental friendliness, recyclability and the cost effectiveness of EPS panels also impacted largely on the factors influencing its usage.

The purpose of this research is to establish that Expanded Polystyrene Systems (ESP) is a sustainable building material with various uses as well as application on the building construction industry. It is of great importance not to talk for the eco-system friendliness to the environment. The aim of this study is to assert that there is a need for the use of Expanded Polystyrene Systems (EPS) as a sustainable substitute to the traditional building material (block and brick) in the building industry. Hence this research attempts to create awareness on the importance and various use of polystyrene in the construction industry, ranging from floor, roof, and wall respectively. This research took on the descriptive method of research. Data was collected through questionnaire. The form of questionnaire adopted was the likert ordinal scale, proceeding ranked into strongly agreed, agreed, disagreed strongly disagreed. The form of administration of the questionnaire to the respondents by the researcher is by hand. However, among the forty respondents who questionnaires were distributed to; only twenty-five questionnaires were recovered. Therefore, only the questionnaire of 25 respondents which represents about $62.5 \%$ response rate were recovered. However, fifteen questionnaires were unable to be recovered which represents about $37.5 \%$. The research data gathered was analysed through the use of descriptive statistic method (mean and standard deviation) and a decision rule was adopted to analyze the calculated mean of each table. Results from the findings of this research shows that expanded polystyrene system (EPS) is a better and sustainable substitute to block and brick.

\section{CONCLUSION}

This study has attempted to evaluate the perception of stakeholders on the use of expanded polystyrene (EPS) for building construction in Nigerian construction industry. It identified individuals with great enthusiasm in the production and use of EPS for building construction but this has not been rewarded with an enabling environment. This inevitably results in the slow pace of adoption of EPS in the building construction. Hence, this study fixed its focus on assessing the factors responsible for the slow adoption pace first by assessing the perception of stakeholders at different levels.
Further study on the use of EPS urged that progress be made by government and other critical stakeholders to conduct proper orientation on EPS use and its adoption as a major component in building construction it has proven to be a more sustainable material.

Other factors are low knowledge base of the public about the workings (source, production, installation, and variant uses) of EPS is a critical impeding factor in the adoption pace. Data analyzed from this study indicates that all benefits expected from the use of an EPS constructed building were mostly derived.

\section{Recommendations}

Having carried out this research, I recommend that:

Government should embark on increasing awareness of EPS to the general public and encourage universities to include EPS study on their teaching and research curriculum.

Government should enforce purposeful reforms aimed at revitalizing the petrochemical industry that will among other objectives, henceforth make it account for styrene, for the domestic market. This will ultimately reduce if not totally stop importation of styrene to achieve resource conservation.

Standard Organizational of Nigeria (SON) should enforce standard in EPS products and also broaden its scope to partnering with Universities and Research Institutions for optimal results towards consumer safety.

EPS manufacturers themselves must engage in self-regulation/governance in addition to SON's regulation, through regular training of their staff on manufacturing best practices and keep abreast of recent developments in fault detection and risk management.

Users alike must place quality assurance in top priority through collaboration in workshop and training of builders and artisans towards client satisfaction and promotion of institutional integrity.

Manufactures should sensitize the public on awareness of EPS through collaboration with government at all level, organized private sector, and other key stakeholders in order to quicken the adoption rate and broaden its market share.

This research further intensifies efforts on EPS towards achieving sustainable housing delivery in Nigeria which was previously recommended by Ogundiran and Adedeji [9]. This in turn, enhances proper resource conservation and leads to sustainable development. 


\section{Contributions}

At the end of this research, it is expected that an awareness on the use of polystyrene to be created, retrospectively causing a lesser overall cost of projects, lesser time for completion of various milestones in projects. This will be beneficial to all building construction stake holders with an aim of maximising satisfaction and minimize cost. From a bigger picture, it benefits the construction industry at large with its easier, time saving and better structural properties.

\section{DECLARATIONS}

\section{Acknowledgements}

The authors would like to thank Zanzan Uji, Professor at University of Jos, Plateau State for his invaluable support in the development of this research paper.

\section{Competing interests} interests.

The authors declare that they have no competing

\section{REFERENCES}

1. Laryea S, Leiringer RT, Hughes W. (2011). Keynotes, programme and abstracts of the West Africa Built Environment Research (WABER) Conference 2011. West Africa Built Environment Research (WABER) Conference. Google Scholar

2. Ede AN, Ogundiran A. (2014). Thermal behaviour and admissible compressive strength of expanded polystyrene wall panelsof varying thickness. Current Trends in Technology and Science. 3(1):110-7. Google Scholar

3. Adedeji YM and Fa G (2012). Sustainable housing provision: preference for the use of interlocking masonry in housing delivery in Nigeria. Architecture Research. 2(5):81-6 https://www.e3journals.org/cms/articles/1330780014_Adedeji\%20 and $\% 20 \mathrm{Fa} . \mathrm{pdf}$

4. Agarwal S, Gupta RK. (2017). Plastics in buildings and construction. In Applied Plastics Engineering Handbook 2017 Jan 1 (pp. 635-649). William Andrew Publishing. https://doi.org/10.1016/B978-0-323-39040-8.00030-4

5. Aminudin E, Din MF, Mohamad Z, Noor ZZ, Iwao K. (2011). A review on recycled expanded polystyrene waste as potential thermal reduction in building materials. InInternational Conference on Environment and Industrial Innovation 2011 Jun (Vol. 12, pp. 113-118). Google Scholar

6. Boser R, Ragsdale T, Duvel C. (2002). Recycled foam and cement composites in insulating concrete forms. Journal of Industrial Technology. 18(3). Google Scholar

7. Goodier K (2009). Making and Using an Expanded Plastic. New Scientist 240: 706. Google Scholar

8. John N. Y. (2004). Flint Hills Resources OSHA Material Safety data Sheet 2004 Available: http//www.fibca.com

9. Ogundiran IA, Adedeji YM. (2012). Urban housing delivery: Expanded polystyrene panels initiative in Abuja, Nigeria. InProcs 4th West Africa Built Environment Research (WABER) $\begin{array}{lll}\text { Conference } & 2012 \quad \text { (pp. }\end{array}$ https://www.academia.edu/download/39556508/WABER_Procs_2 012___Vol_2.v3.pdf\#page $=331$

10. EPS Packaging Group - EPG (2013). Expanded Polystyrene (EPS) and the Environment. www.epg.org

11. Drysdale D. (2011). An introduction to fire dynamics. ., 2nd ed John Wiley \& Sons, Inc: West Sussex, UK. 2011 Aug 24. Google $\underline{\text { Scholar }}$
12. Saint-Gobain, I. (2009). Planet, people, prosperity: Our commitment to sustainable construction. Retrieved from www.isover.com on 26th September, 2013.

13. Sulong et al. (2018). Housing for low-income workers in developing countries: a Nigerian case study; ISBN 978-3-84848035-7, LAP Lambert Academic Publishing, GmbH \& Co. KG, Saarbrücken, Germany, p. 156

14. Brydson, (2009). Urban housing delivery: Expanded polystyrene panels initiative in Abuja, Nigeria. In Laryea, S., Agyepong, S.A., Leiringer, R. and Hughes, W. (Eds). Procs 4th West Africa Built Environment Research (WABER) Conference, 24-26 July 2012, Abuja Nigeria 1033 - 1042.

15. Kellenberger D, Althaus HJ, Jungbluth N, Künniger T, Lehmann M, Thalmann P. (2007). Life cycle inventories of building products. Final report ecoinvent data v2. 0 No. 2007 Dec; 7. https://scholar.google.com/scholar?cluster $=8447197985523192229$ \&hl=en\&as sdt $=2005 \&$ sciodt $=0,5$

16. Ilesanmi AO. (2010). Urban sustainability in the context of Lagos mega-city. Journal of Geography and Regional Planning. 3(10):240-52.

https://scholar.google.com/scholar?cluster=770344590277836133 \&hl=en\&as_sdt $=2005 \&$ sciodt $=0,5$

17. Muhammad IB. (2010). Wood as a Sustainable Building Material in Nigeria. Proceedings of the Architects Colloquium Shehu Yar'adua Centre Abuja, Nigeria. http://repository.futminna.edu.ng:8080/jspui/handle/123456789/28 $\underline{30}$

18. Olotuah AO. (2002). An appraisal of the impact of urban services on housing in Akure Metropolis. Journal of Science, Engineering and Technology. 9(4): 4570-82. Google Scholar

19. Prucnal-Ogunsote, Okwoli and Ude, (2010). Report on expanding the scope and market of SIP technologies: a history of SIPs and CSIP manufacturing, construction and market issues, The Federation of American Scientist.

20. Saint-Gobain, I. (2009). Planet, people, prosperity: Our commitment to sustainable construction. Retrieved from www.isover.com on 26th September, 2013.

21. Wang L, Wang C, Liu P, Jing Z, Ge X, Jiang Y. (2018). The flame resistance properties of expandable polystyrene foams coated with a cheap and effective barrier layer. Construction and Building Materials. 176: 403-14. https://doi.org/10.1016/j.conbuildmat.2018.05.023

22. Miao L, Wang F, Han J, Lv W, Li J. (2003). Properties and applications of cement-treated sand-expanded polystyrene bead lightweight fill. Journal of Materials in Civil Engineering. 25(1): 86-93. https://doi.org/10.1061/(ASCE)MT.1943-5533.0000556

23. Lstiburek JW. (2008). Builder's Guide: To Structural Insulated Panels (SIPs) for All Climates. Building Science Corporation; 2008. Google Scholar

24. Van Dorp, T. (1988). In International Conference on Expanded Polystyrene, Milan, Italy.

25. Ferrándiz-Mas V, García-Alcocel E. (2013). Durability of expanded polystyrene mortars. Construction and Building Materials. $46: \quad 175-82$. https://doi.org/10.1016/j.conbuildmat.2013.04.029

26. Van D, Van Dijk HA. (1980) Smoke Problems in Buildings on Fire: A TNO Research Project. https://pascalfrancis.inist.fr/vibad/index.php?action=getRecordDetail\&idt=PAS CALBTP8130164854

27. Vaidya A, Uddin N, Vaidya U. (2010). Structural characterization of composite structural insulated panels for exterior wall applications. Journal of Composites for Construction. 14(4):464-9. https://doi.org/10.1061/(ASCE)CC.1943-5614.0000037

28. Aminudin E, Din MF, Mohamad Z, Noor ZZ, Iwao K. (2011). A review on recycled expanded polystyrene waste as potential thermal reduction in building materials. InInternational Conference on Environment and Industrial Innovation. 12: 113-118. Google $\underline{\text { Scholar }}$ 